\title{
集中荷重を受ける複合炭素繊維補強コンクリート造円筒殼の耐力 STRENGTH OF CONCRETE CYLINDRICAL SHELLS REINFORCED WITH COMPOSITE CARBON FIBER UNDER CONCENTRATED LOAD
}

\author{
川崎 健二郎*, 䢐下 和 彦** \\ Kenjiro KAWASAKI and Kazuhiko MASHITA
}

\begin{abstract}
The main purpose of this study is to investigate, both experimentally and theoretically, the strength of concrete cylindrical shells with composite carbon fiber reinforcement under concentrated load. It is defined in this study that composite carbon fiber reinforcement consists of carbon fiber chips and carbon fiber sheets. The chips and the sheets could improve the tensile strength of a concrete shell in its internal and external regions, respectively. An experimental study was conducted on concrete shells reinforced with composite carbon fiber under concentrated load. A theoretical study was conducted by material and geometrical nonlinear finite element analyses including tension cutoff and tension stiffening effects. The ultimate strength of the shell with composite carbon fiber reinforcement was discussed on the basis of the results of the fracture experiments and nonlinear analyses.
\end{abstract}

Keywords : Concrete Shell, Carbon Fiber Chip, Carbon Fiber Sheet コンクリートシェル，炭素短絨維, 炭素瀻維シート

\section{1. 序論}

コンクリートシェル構造は, 自由で多様な空間形態の創造が可能 であり、これまで，幾多の著名な設計者により歴史的建築構造物が 建設されると共に，主として分布荷重を対象とした実験的研究が行 われ，シェルの力学的特性が明らかにされてきた ${ }^{1-4)}$ 。近年, 破壊 実験との比較検討を混えて，特定の境界条件を対象とした耐力評価 式 $^{5)}$ 及び数值解析 ${ }^{6,7)}$ により耐力の評価が可能となってきた。高い 㓦荷能力を有するコンクリートシェル構造は，内部空間および外部 空間を同時に多目的利用したり，災害時の避難施設として使用でき る可能性を有しているが, 従来のコンクリートシェル構造の補強は, 鉄筋の錆等による経年変化の問題も䋅念されてきている。こうした 中で，新素材によるコンクリート補強が提案され，中でも炭素緎維 補強は，軽量，高耐力，高対候性等の特徴を有し，注目されている 8)。炭素繊維シート補強は, 主として橋脚や柱の補強等八の応用が 報告されているが，コンクリートシェル構造への適用は殆ど検討さ れていない。加えて，炭素短緎維補強によるコンクリートシェル 構造への応用は，筆者等の報告を除くと ${ }^{9)}$ ，殆ど報告されていな い。本研究においては，これまで筆者等が検討を行ってきた炭素短 緎維補強コンクリート (Carbon Fiber Chip Reinforced Concrete; CFCRC）造に対して，新たに炭素瀻維シート補強を同時併用した補 強形態として, 複合炭素䋊維補強コンクリート (Composite Carbon Fiber Reinforced Concrete；CCFRC) 造シェルを提案し，これによ
るシェルの酎力と破壊形態を実験的及び数値解析的に検証を行い， 基礎的検討を行ったのでその結果を報告する。なお，比較のために， 従来の鉄筋コンクリート $(\mathrm{RC})$ 造シェルに，炭素繊維シート補強を 施した炭素䋗維シート補強鉄筋コンクリート (Carbon Fiber Sheet Reinforced Concrete; CFSRC) 造シェルの破壊実験および非線形数 值解析を実施し，これらの結果と比較検討を行った。加えて，炭素 緎維シート補強の貼付領域を変化させて，シェルの耐力に及ぼす効 果に関しても検討を加えた。以上より，複合炭素䋐維補強コンクリ一 ト造シェルの耐力並びに破壊形態の特徴を明らかにした。更に，炭 素緎維シート補強領域が，シェルの䩂力に及ぼす影響を明示すると 共に，従来の鉄筋コンクリート造シェルの場合と対比させて，炭素 綫維シート補強がシェルの耐力へ及ぼす影響を明らかにした。

\section{2. 破壊赛験の概要}

コンクリート造円筒殼を対象として，シェル面中央部に静的点 荷重が作用した場合に於けるシェルの耐力及びひび割れ形態を実 験的に検討する為, CFCRC 造 1 体, CCFRC 造 2 体, RC 造 1 体及び CFSRC 造 2 体で合計 6 体の小型実験供試体を作製し，破壊実験を 行った。尚,Fig. 1 に本破壊実験で用いた実験供試体並びに載荷位 置の図を示す。実験供試体寸法は水平投影面に於いて $1120 \mathrm{~mm}$ (L1) $\times 1120 \mathrm{~mm}$ (L3) の正方形とし，ライズ・スパン比を $1 / 5$ (L2/L1，L2： ライズ) とした。尚, 曲率半径 $812 \mathrm{~mm}$, 全開角 $87.1^{\circ}$ となる。シェ
* 東海大学工学研究科 大学院生

** 東海大学工学部建築学科 教授. 工博
Graduate Student, Graduate School of Eng., Tokai Univ.

Prof., Dept. of Architecture and Building Eng., Faculty of Eng., Tokai Univ., Dr. Eng. 
ル境界を，縁部材幅及びせいが $40 \mathrm{~mm} の$ 縁ア一チ及び粶梁により補 剛した。各縁部材配筋は, 主筋にD3 の異形鉄筋を使用し, あばら 筇として $\phi 0.85 \mathrm{~mm}$ の鉄線を $20 \mathrm{~mm}$ 間隔とした。CFCRC 造及び CCFRC 造の調合はセメント対骨材の重量比を 1 対 1 ，水セメント比を $37 \%$ とした。更に，炭素短瀻維をセメント重量比に対して $4 \%$ ，その添 加鼡としてメチルセルロースを0.25\%混入した。一方, CFSRC 造の シェル面内配筋注 $\phi 1.2 \mathrm{~mm}$ の鉄線を $20 \mathrm{~mm}$ 間隔で単配筋とした。炭 素繊維シートは一層の平織りを採用した。シートは $17 \mu \mathrm{m} の$ 束を 織り込んであり，その厚さは $0.19 \mathrm{~mm}$ である。このシートを直交二 方向, 即ちシェルの母線方向と円弧方向となる様, エポキシ樹脂 でコンクリート面に接着した。Fig. 2 は，シェル中央部に集中荷重 が作用した場合に，引張応力度が卓越寸る領域を選定し比較検討を 行うためのシート貼り付け位置を選定したものである。即ち, FT12 及びRT12 は, シェル表面粶梁近接領域であり, FB11 とRB11 は, シェ
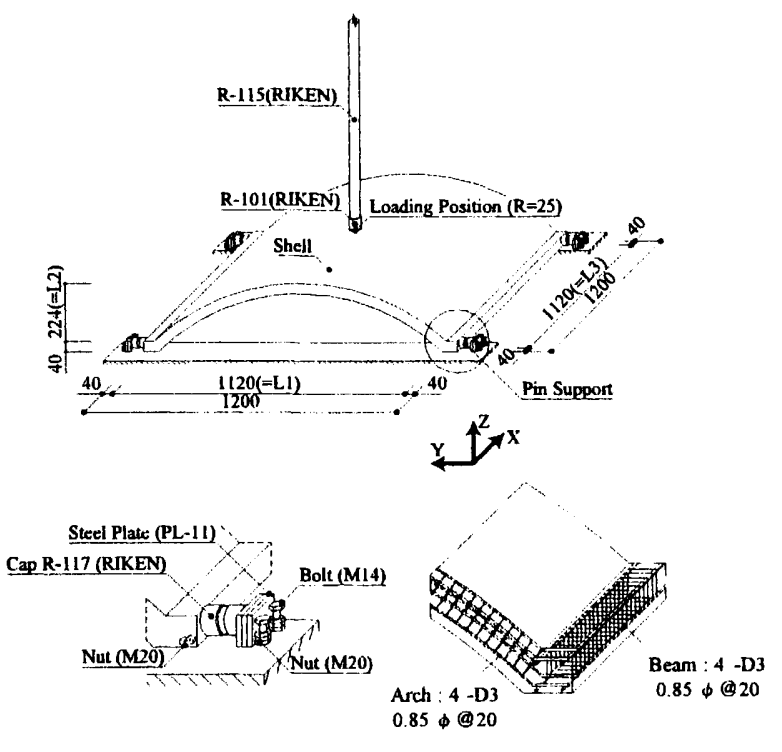

Note ) RIKEN : Manufactured by Rikenkiki

Fig.1 Loading System and Boundary Condition.

Table 1 Shell Model.

\begin{tabular}{|c|c|c|c|c|c|c|c|c|c|c|}
\hline \multirow{4}{*}{ Model } & \multicolumn{4}{|c|}{ Label $=[1]-[2]-[3]-[4]$} & \multirow{2}{*}{\multicolumn{4}{|c|}{ Material Properties of Concrete }} & \multirow{2}{*}{\multicolumn{2}{|c|}{ Shell Thickness [mm] }} \\
\hline & [1] & {$[2]$} & & & & & & & & \\
\hline & \multirow{2}{*}{$\begin{array}{c}\text { Material } \\
\text { Properties }\end{array}$} & \multirow{2}{*}{$\begin{array}{c}\text { Reinforced } \\
\text { Surface }\end{array}$} & \multicolumn{2}{|c|}{$\begin{array}{l}\text { Reinforced } \\
\text { Region }\end{array}$} & \multirow{2}{*}{$\begin{array}{l}\text { Young's } \\
\text { Modulus } \\
\text { : E [GPa] }\end{array}$} & \multirow{2}{*}{$\begin{array}{c}\text { Ultimate } \\
\text { Compressive } \\
\text { Strength } \\
\mathrm{F}_{\mathrm{c}}[\mathrm{MPa}]\end{array}$} & \multirow{2}{*}{$\begin{array}{c}\text { Ultimate } \\
\text { Tensile } \\
\text { Sirength } \\
\text { F, [MPa] }\end{array}$} & \multirow{2}{*}{$\begin{array}{c}\text { Poisson's } \\
\text { Ratio } \\
; v\end{array}$} & \multirow{2}{*}{ Average } & \multirow{2}{*}{$\begin{array}{l}\text { Standard } \\
\text { Deviation }\end{array}$} \\
\hline & & & $\mathrm{x}$ & $\mathrm{y}$ & & & & & & \\
\hline FNNN & \multirow{6}{*}{$\begin{array}{l}\text { F: Carbon Fiber Chip } \\
\text { Reinforced Concrete }\end{array}$} & \multirow{2}{*}{$\mathrm{N}$ : None } & - & - & 26.6 & 69.2 & 7.16 & 0.234 & 9.37 & 2.19 \\
\hline FT12 & & & $\pm 1 / 4$ & $\pm 2 / 4$ & 22.8 & 65.7 & 7.05 & 0.250 & 9.65 & 1.90 \\
\hline FB11 & & \multirow{2}{*}{ T: Top } & $\pm 1 / 4$ & $\pm 1 / 4$ & 27.8 & 78.3 & 6.52 & 0.232 & 9.23 & 2.29 \\
\hline RNNN & & & - & - & 26.1 & 67.4 & 3.62 & 0.195 & 11.6 & 2.23 \\
\hline RT12 & & \multirow[t]{2}{*}{ B : Bottom } & $\pm 1 / 4$ & $\pm 2 / 4$ & 22.8 & 65.7 & 3.75 & 0.250 & 11.8 & 2.62 \\
\hline RB11 & & & $\pm 1 / 4$ & $\pm 1 / 4$ & 22.8 & 65.7 & 3.75 & 0.250 & 9.33 & 2.49 \\
\hline
\end{tabular}

Table 2 Material Properties of Steel Bar. Table 3 Material Properties of Carbon Fiber Sheet.

\begin{tabular}{|c|c|c|c|c|c|c|c|c|c|c|c|c|}
\hline $\begin{array}{c}\text { Steel Bar } \\
\text { Diameter } \\
{[\mathrm{mm}]}\end{array}$ & $\begin{array}{c}\text { Young's } \\
\text { Modulus } \\
\text { [GPa] }\end{array}$ & $\begin{array}{c}\text { Yield } \\
\text { Strength } \\
{[\mathrm{MPa}]}\end{array}$ & $\begin{array}{c}\text { Ultimate } \\
\text { Tensile } \\
\text { Strength } \\
\text { [MPa] }\end{array}$ & Type & Texture & $\begin{array}{c}\text { Fiber } \\
\text { Diameter } \\
{[\mu \mathrm{m}]} \\
\end{array}$ & $\begin{array}{c}\text { Tensile } \\
\text { Strength } \\
\text { [GPa] }\end{array}$ & $\begin{array}{c}\text { Tensile } \\
\text { Elasticity } \\
\text { Modulus } \\
\text { [GPa] }\end{array}$ & $\begin{array}{c}\text { Elongation } \\
\text { [\%] }\end{array}$ & $\begin{array}{l}\text { Density } \\
{\left[\mathrm{N} / \mathrm{mm}^{3}\right]}\end{array}$ & $\begin{array}{l}\text { Specific } \\
\text { Gravity }\end{array}$ & $\begin{array}{l}\text { Weight } \\
{\left[\mathrm{N} / \mathrm{mm}^{2}\right]}\end{array}$ \\
\hline 0.85 & 186 & 162 & 250 & \multirow{3}{*}{ TR3110MS } & \multirow{3}{*}{ Plain Fabric } & \multirow{3}{*}{17.0} & \multirow{3}{*}{1.12} & \multirow{3}{*}{71.6} & \multirow{3}{*}{1.50} & \multirow{3}{*}{$1.03 \times 10^{-5}$} & \multirow{3}{*}{1.90} & \multirow{3}{*}{$1.96 \times 10^{1-6}$} \\
\hline 1.20 & 235 & 364 & 468 & & & & & & & & & \\
\hline D3 & 198 & 334 & 487 & & & & & & & & & \\
\hline
\end{tabular}

Table 4 Material Properties of Carbon Fiber Chip.

\begin{tabular}{|c|c|c|c|c|c|c|}
\hline Type & $\begin{array}{c}\text { Fiber } \\
\text { Length } \\
(\mathrm{mm})\end{array}$ & $\begin{array}{c}\text { Fiber Diameter } \\
(\mu \mathrm{m})\end{array}$ & $\begin{array}{c}\text { Tensile } \\
\text { Strength } \\
(\mathrm{GPa})\end{array}$ & $\begin{array}{c}\text { Tensile } \\
\text { Elasticity } \\
\text { Modulus } \\
(\mathrm{GPa})\end{array}$ & $\begin{array}{c}\text { Specific } \\
\text { Gravity } \\
(\%)\end{array}$ & $\begin{array}{c}\text { Density } \\
\left.(\mathrm{N} / \mathrm{mm})^{3}\right)\end{array}$ \\
\hline $\mathrm{K} 661$ & 18.0 & 17.0 & 1.77 & 180 & 1.00 & $1.90 \times 10 \%$ \\
\hline
\end{tabular}




\section{3. 数値解析の概要}

\section{1 非線形有限要素解析}

複合炭素瀻維補強コンクリート造円筒款の耐力及び力学的非線形 特性を理論的に検討する為，コンクリート引張剛性及びひび割れを 考慮した材料及び幾何学的非線形有限要素解析を適用した。

解析で使用した要素は，双二次ラグランジェ (Lagrange) 型の変 位関数を有する 9 節点アイソパラメトリック系積層シェル要素であ る。材料非線形解析に於いて,コンクリートの圧縮挙動に対しては, ドラッカー・ブラガー（Drucker-Prager） 型降伏関数を使用した。 コンクリート終局圧維歪は 0.003 とし，この值を超える場合には压 壊と判定した。コンクリートの引張挙動に対して,ひび割れ判定を 行い,ひび割れ発生後は引張剛性を考虑した。引張剛性はコンクリ一 卜終局引張強度 $\mathrm{F}_{\mathrm{t}}$ の 6 割 (RC 造)，または 8 割 (CFSRC, CFCRC 及 びCCFRC 造）の応力度を歪に反比例させて計算を行った。なおうこ れらの引張剛性に関する応力度歪み度曲線をFig. 3(a) に示した。 更にFig. 3(b) に, 文献 10) と同様に, 引張剛性パラメー夕 $(\alpha)$ と終局引張歪み $(\varepsilon \mathrm{m})$ の変動に伴う終局耐力図を, FNN において 示した。同図は，上述のコンクリート終局引張強度の 8 割の応力度 を歪みに反比例させた計算結果が，破壊実験の耐力を若干下回り， 安全側の対応を示している。鉄筋の応力ー歪関保には,バイリニアー 型 (Bilinear)を適用した。

\section{2 計算の概要}

本計算では，シェル板厚及び材料諸元に基づき 3 種の解析モデ ルを設定した。最初は基準モデルである。これは、シェル板厚を 設阡板厚の $8 \mathrm{~mm}$ に設定しコンクリートの材料定数を一定値 (ヤング 係数 $\mathrm{E}=21 \mathrm{GPa}$ ，圧樎強度 $\mathrm{F}_{\mathrm{c}}=60 \mathrm{MPa}, \mathrm{RC}$ 造及び $\mathrm{CFSRC}$ 造の引張強度 $\mathrm{F}_{\mathrm{t}}=3 \mathrm{MPa}, \quad$ CFCRC 造及び CCFRC 造の引張強度 $\mathrm{F}_{\mathrm{t}}=6 \mathrm{MPa}$, ポアソン比 $v$ =0.20)に設定したものである。次は，個別板厚モデルである。これは， シェル全面に渡って板厚変動を忠実に再現したモデルであり, 材料 定数は個々の実験供試体と一致させたものである。最後は, 平均板 厚モデルである。これは、シェル板厚として寒験供試体の実測板厚 の平均值を採用したモデルであり，材料定数は，個別板厚モデルと 同様である。

3. 3 炭素繊維シートのモデル化

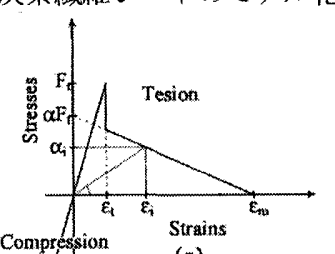

(a)

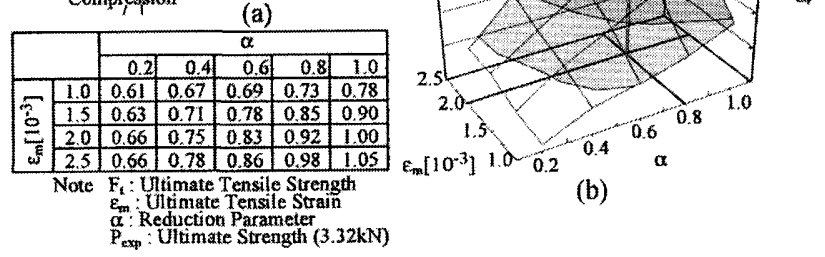

Fig.3 Tension Stiffening.
炭素瀻維シート補強の数值モデルの設定は下記の通りである。 シートは直交二方向，即ちシェルの母線方向と円弧方向に，それぞ れ伸び岡性を有し，その面内せん断㴊性汇期待できない。樹脂を接 着した炭素繊維シートの基礎的な数值モデル作成において，面内せ ん断剛性を考慮した場合を板剛性モデル (Plate Stiffness Model) として，また面内せん断剛性を無視した直行二方向の直応力のみで 抵抗する場合を，直㴊性モデル (Normal Stiffness Model) として 定義した。綫維方向となるシェルの母線と指導線に平行な方向の引 張及び圧維強度は炭素瀻維シートに対応する強度とそれぞれ一致さ せた。更に，シートのヤング係数は，コンクリートの3 倍程度が示 されているが，接着剤を含んだシートのヤング係数に関する十分な 資料が得られないため，本研究では，シートのヤング係数の下限值 として，コンクリートのヤング係数と同一にした場合の (Table 5 の Concrete) と，その上限值としてシートのヤング係数と同一にし た場合 (Table 5 の Sheet) の 2 種を設定した。また, ポアソン比は, 上記のコンクリートと設定した場合には，コンクリートと同程度に 仮定し，シートと設定した場合には，膜構造の資料の一例を参照し $\tau^{11)} ， 0.4$ を採用した。以上を継めてTable 5 に示した。同表の PSCC は，板剛性，シートの引張と圧縮強度，及びコンクリートの ヤング係数とポアソン比に仮定した。PSSS は，板剛性，シートの 引張と圧縮強度, 及びシートのヤング係数とポアンン比に仮定した。 NSC ほ，直剛性，シートの引張と圧縮强度，及びコンクリートのヤ ング係数に仮定した。NSS は, 直剛性, シートの引張と圧樎強度， 及びシートのヤング係数に仮定した。上記の 4 タイプによる平均板 厚モデルのひび割れ図を，実験供試体 RB11 及び FB11 の場合と比較 して，Fig. 4 に示した。さらに，RB11 及びFB11の終局酎力誤差比

Table 5 Numerical Model for Carbon Fiber Sheet.

\begin{tabular}{|c|c|c|c|c|}
\hline Model & Stiffness & $\begin{array}{c}\text { Tensile } \\
\text { Strength }\end{array}$ & $\begin{array}{c}\text { Young's } \\
\text { Modulus }\end{array}$ & $\begin{array}{c}\text { Poisson's } \\
\text { Ratio }\end{array}$ \\
\hline PSCC & Plate & Sheet & Concrete & Concrete \\
\hline PSSS & Plate & Sheet & Sheet & Sheet \\
\hline NSC & Normal & Sheet & Concrete & - \\
\hline NSS & Normal & Sheet & Sheet & - \\
\hline
\end{tabular}

Note) Plate: Plate Stiffness, Nomal : Normal Stiffness, Sheet Tensile Strength : 1.12GPa, Sheet Young's Modulus : $71.6 \mathrm{GPa}$, Sheet Poisson's Ratio : 0.4
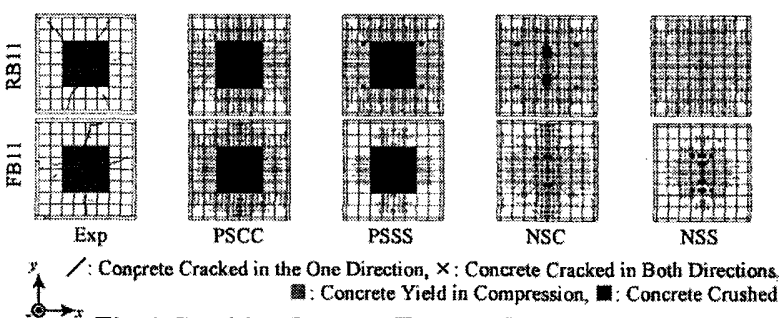

Fig.4 Cracking Pattern (Bottom Surface of B11).

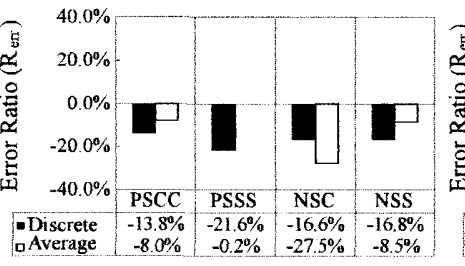

(a) RB11

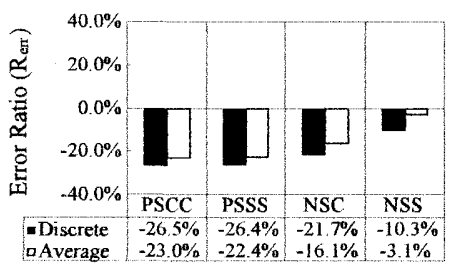

(b) FBII
Fig.5 Error Ratio ( $\left.R_{e r r}\right)$ of Ultimate Strength. 
(Rerr) をFig. 5(a-b) に示した。ここで，終局酎力䛊差比 (Rerr) は, 数値解 $\left(\mathrm{P}_{\mathrm{num}}\right)$ と実験值 $\left(\mathrm{P}_{\mathrm{exp}}\right)$ を用いて，次式により定義した。

$$
\mathrm{R}_{\mathrm{err}}=\left[\mathrm{P}_{\mathrm{num}}-\mathrm{P}_{\mathrm{exp}}\right] / \mathrm{P}_{\mathrm{exp}}
$$

最初に,Fig.4のひび割れ形態より，RB11に関しては, タイプ NSS のみシェル中央部の圧壊が回避されており，実験結果と対応し ている。さらに, FB11に関しては, 破壊実験と同様にタイプNSS において，大幅なひび割れ低減が示されている。

次に, Fig. 5 に示した終局耐力誤差比 (Rerr) において, FB11に関 しては個別板厚モデル及び平均板厚モデル共にNSSの結果が最も䛊 差の少ない良好な対応を示している。また，RB11に関してはPSSS の平均板厚モデルを除くと，タイプNSS は個別板厚モデル及び平均 板厚モデル共に誤差の少ない良好な結果が示されている。

以上より，ひび割れ形態及び耐力整合比を総合的に判断すると, タイプNSSが実験結果に対して最も適応性が良いといえる。従って， 本研究の数値解析においては，炭素瀻維シートの数値モデルとして タイブNSS を採用する。

\section{4 シート補強範进0)選定}

まず，シート補強範囲として，Table 6で示した11種の補強領 域を設定した。その内訳沬，シェルの表裹面に对して，Fig. 6 に示 した 5 種のシート補強範囲をそれぞれ選択し，更に，シート無補強 (NN)を加えた合計 11 補強領域である。

シ一ト補强範囲の選定において，CCFRC 造及びCFSRC 造の 2 種類 について上記の補強領域の解析をそれぞれ行った。间，数值解析王 デルとして，上述の基淮モデルを適用している。

ここで,Fig. 6 に示したシート補強範用は以下の通りである。シー 卜補强範囲は，シェルの水半投影面に於いて母線方向及び指導線方 向それぞれ，各方向の長さの $1 / 2$ とした, Table 6 に示したモデル 名は，1 文字目は構成材料，2 文字目はシート貼り付け面， 3 及び 4 文字目は X及びY方向の補強領域の中心位置を示している。ここで， シェル水平投影面の中心に原点を置き，半スパンに対して無次元化 した座標 $\mathrm{x}$ 及び $\mathrm{y}$ 軸を設定し，この座標系で補強領域の中心位置を

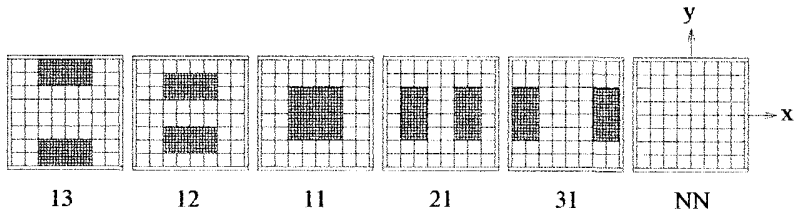

Fig.6 Reinforced Region with Carbon Fiber Sheets.

Table 6 Model Name.

\begin{tabular}{|c|c|c|c|c|}
\hline \multirow{2}{*}{ Model Name } & \multirow{2}{*}{ Materials } & \multirow{2}{*}{$\begin{array}{l}\text { Reinforced } \\
\text { Surface }\end{array}$} & \multicolumn{2}{|c|}{ Reinforced Region } \\
\hline & & & $x_{1}$ & $y_{1}$ \\
\hline $\mathrm{F}(\mathrm{R}) \mathrm{T} 13$ & \multirow{11}{*}{$\begin{array}{c}\text { F: } \\
\text { Fiber Chip } \\
\text { Reinforced } \\
\text { Concrete }\end{array}$} & \multirow{11}{*}{$\begin{array}{c}\text { T: Top } \\
\text { B: Bottom }\end{array}$} & $\pm 1 / 4$ & $\pm 3 / 4$ \\
\hline $\mathrm{F}(\mathrm{R}) \mathrm{T} 12$ & & & $\pm 1 / 4$ & $\pm 2 / 4$ \\
\hline $\mathrm{F}(\mathrm{R}) \mathrm{T} 11$ & & & $\pm 1 / 4$ & $\pm 1 / 4$ \\
\hline $\mathrm{F}(\mathrm{R}) \mathrm{T} 21$ & & & $\pm 2 / 4$ & $\pm 1 / 4$ \\
\hline$F(R) T 31$ & & & $\pm 3 / 4$ & $\pm 1 / 4$ \\
\hline $\mathrm{F}(\mathrm{R}) \mathrm{B} 13$ & & & $\pm 1 / 4$ & $\pm 3 / 4$ \\
\hline $\mathrm{F}(\mathrm{R}) \mathrm{B} 12$ & & & $\pm 1 / 4$ & $\pm 2 / 4$ \\
\hline $\mathrm{F}(\mathrm{R}) \mathrm{B} 11$ & & & $\pm 1 / 4$ & $\pm 1 / 4$ \\
\hline $\mathrm{F}(\mathrm{R}) \mathrm{B} 21$ & & & $\pm 2 / 4$ & $\pm 1 / 4$ \\
\hline $\mathrm{F}(\mathrm{R}) \mathrm{B} 31$ & & & $\pm 3 / 4$ & $\pm 1 / 4$ \\
\hline $\mathrm{F}(\mathrm{R}) \mathrm{NNN}$ & & & - & - \\
\hline
\end{tabular}

示した。補強領域の中心点の座標として $1 / 4 ， 2 / 4$ 及び $3 / 4$ を採用 した。

これらの数値解析結果より, シート補強効果の検討を行い, その 結果をFig. 7 に示した。同図は，次式で定義したシート補強終局耐 力比 $\left(\mathrm{R}_{\text {sht }}\right)$ を示している。ここで, シート補強終局耐力比 $\left(\mathrm{R}_{\text {sht }}\right)$ は, シート有無の各耐力 $\left(\mathrm{P}_{\mathrm{nnn}}, \mathrm{P}_{\mathrm{sht}}\right)$ を用いて, 次式により定義した。

$$
\mathrm{R}_{\text {sht }}=\left[\mathrm{P}_{\text {sht }}-\mathrm{P}_{\mathrm{nnn}}\right] / \mathrm{P}_{\mathrm{nnn}}
$$

同図のCFSRC 造において,シェル裏面中央（補強領域 11）及びシェ ル表面縁梁近接領域（補強領域 12）のシート補強がシェルの耐力増 大に効果的であると考えられる。一方，CCFRC 造において，シェル 表聖面中央（補強領域 11）及びシェル表面縁梁近接領域（補強領域 12）の補強が耐力增大に有効であると考えられる。但し，CCFRC 造 よりもCFSRC 造においてシート効果が顕著に示されている。また， CCFRC 造のシェル裏面縁梁近接領域（補強領域 12）及びシェル表裏 面秝アーチ隣接領域（補強領域 31）では，耐力減少も見られる。こ れは，引張り応力場が支配的でない領域に対寸るシート補強により 局部的な変形拘束が生じ，載荷占近傍の変形能力を減少させたこと により，若千のシェルの耐力低下を招いたものと考えられる。

上記の結果を総合的に判断して，シート補強㕮果が期待される補 強領域 11 及び補強領域 12 を対象として奏験及び数值解析を行った。

\section{4. 結果及び考察}

\section{1 シェルの酎力}

破壊実験による耐力に対して，数值計算による耐力から破壊実験 による酎力を差し引いた耐誤差との比を求め, 酎誤差比として, Fig. 8 に示した。数値計算として，平均板厚及び個別板厚の両者を 比較して示した。尚，実験の終局耐力は，同図の括弧内に示した通り， RNNN で $5.79 \mathrm{kN}$, RT12 で $4.67 \mathrm{kN}, \mathrm{RB} 11$ で $5.26 \mathrm{kN}$, FNNN で $3.32 \mathrm{kN}$, FT12で5.04kN，FB11で6.14kN が示された。CCFRC 造の実験終局 耐力は，FNNNに比べFB11 で $86 \%$ 増，FT12 で52\%増が示され，シー 卜補強により著しい補强効果が確認された。しかし FNNNの載荷点

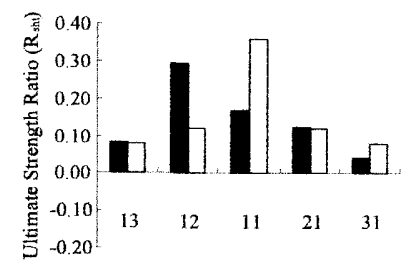

(a) CFSRC

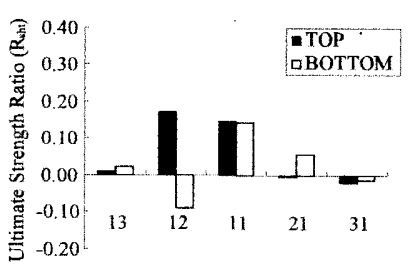

(b) CCFRC
Fig.7 Ultimate Strength Ratio $\left(\mathrm{R}_{\text {sht }}\right)$ by Sheets.

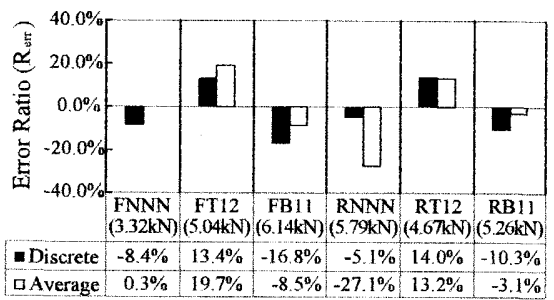

Fig.8 Error Ratio $\left(\mathrm{R}_{\text {err }}\right)$ of Ultimate Strength. 
直下の板厚が他の供試体より薄いことが確認され，シート補強によ る耐力増大は幾分過大評価されたものと考えられる。CFSRC 造の実 験終局耐力は, RNN に比べRT12, RB11 共に耐力減少が示された。 これは, RNNNの載荷点直下の板厚が他の供試体より厚いことに起 因しているものと考えられる。

シート無しの RNNN は，平均板厚モデルの)終局耐力誤差比 $27.1 \%$ 減に対し, 個別板厚モデルの終局耐力誤差比 $5.1 \%$ 减が示され, 板 厚変動を忠実に反映した個別板厚モデルの有効性が確認された。一 方, シート無しのモデル FNNNでは, 平均板厚モデルの終局耐力誤 差比 $0.3 \%$ 增及び個別板厚モデルの終局耐力誤差比 $8.4 \%$ 减が示され た。これは，施工板厚分布が比較的均一であることに起因している ものと思われる。以上より,シート無補強の場合は, 平均板厚モデ ルより個別板厚モデルの方が実際の耐力に近い結果を得る可能性が 高いと考えられる。

炭素瀻維シート補強された場合は, FT12で個別板厚モデルの方 が平均板厚モデルより若干良好な対応を示しているが，その他の全 てのモデルで個別板厚モデルより平均板厚モデルの方が実験結果と 良く一致している。これは, シート補強により板厚変動が軽滅され て, シート補強領域の板厚均一化効果が示されたものと考えられる。

次に, シ一下補強終局耐力比 $\left(\mathrm{R}_{\text {sht }}\right)$ を個別板厚モデル及び平均板 厚モデルの各解析結果に対して求め, Fig. 9 に示した。シート補強 終局耐力比 $\left(\mathrm{R}_{\mathrm{sht}}\right)$ は，各シート補強有りのモデルに対忘したシート 無しモデルの解析を行い，その終局耐力に対する比として求めた。 同図より，RB11 の平均板厚モデルの $38.7 \%$ 増から FT12 の個別板厚 モデルの 3.9\%増の耐力増大が示されている。シート補強範囲に関 しては, 補強領域 11 の方が補強領域 12 より耐力増大に貢献してい る。また，CFSRC 造は，CCFRC 造よりシート補強効果が顕著である。

\section{2 耐力補正}

次に，破壊実験の終局耐力から炭素繊維シート補強効果が明確 には確認されなかった為, 施工板厚の変動を考慮し, 耐力の検証を 行った。破壊実験より得られた各供試体の比較及び耐力補正結果を Table 7 に示す。各比率はシート無補強モデル RNNN(鉄筋補強) 及 び FNNN（炭素短㵶維補強）に対する各対応シート補強モデルの值を

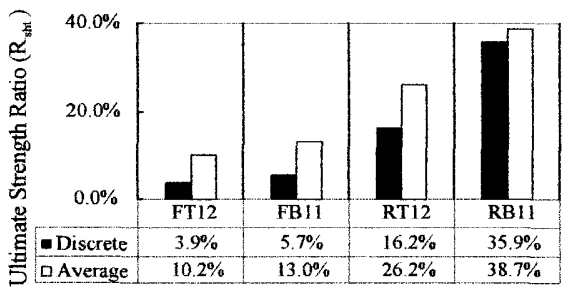

Fig.9 Ultimate Strength Ratio $\left(\mathrm{R}_{\text {sht }}\right)$ by Sheet.
示している。同表のE00は，破壊実験の終局耐力を基に，シート無 補強タイプの耐力に対する各シート補強タイプの耐力の耐力比を 示している。同様に，S00 は，設定板厚 $(8 \mathrm{~mm})$ 及びコンクリート材 料諸元を統一した場合の基淮数值モデルより得られた基淮耐力比で ある。E00の値は，供試体の板厚が均一で，設計板厚に近ければ， S00 の耐力比と対羗てくると予想され，これにより実験と数值計 算の耐力の整合性が確認できる根拠となり得ると考えられる。その 整合比を 110 として揭載した。即ち，E10は，上記 S00に対する比 率として求めた酎力整合比である。TG1 は，シェル全面における板 厚実測値の平均値に基づく全面板厚比であり, TL1 は, 集中荷重の 載荷点直下を含み，その隣接した限定領域，即ちシェル幅と長さの 各 $1 / 4$ の限定領域内の平均板厚に基づく限定板厚比である。これら による実験酎力の線形・二次・三次補正を求め, 上記 $\mathrm{S} 00$ との各整 合比を, シェル全面の平均板厚に関して $\mathrm{EG1}, \mathrm{EGI}^{2}, \mathrm{EGI}^{3}$, 載荷点直 下近傍の平均板厚に関して EL1, $\mathrm{EL}^{2}{ }^{2}, \mathrm{EL} 1^{3}$ としてそれぞれ示した。 以上を䌖めて，次式より，各整合比を求めた。

$\mathrm{E} 10=\mathrm{E} 00 / \mathrm{S} 00, \mathrm{EG} 1=(\mathrm{E} 00 / \mathrm{TG} 1) / \mathrm{S} 00, \mathrm{EG}^{2}=\left(\mathrm{E} 00 / \mathrm{TG}^{2}\right) / \mathrm{S} 00$, $\mathrm{EG}^{3}=\left(\mathrm{E} 00 / \mathrm{TG}^{3}\right) / \mathrm{S} 00, \quad \mathrm{EL} 1=(\mathrm{E} 00 / \mathrm{TL} 1) / \mathrm{S} 00$,

$\mathrm{EL}^{2}=\left(\mathrm{E} 00 / \mathrm{TL}^{2}\right) / \mathrm{S} 00, \mathrm{EL}_{1}^{3}=\left(\mathrm{E} 00 / \mathrm{TL}^{3}\right) / \mathrm{S} 00$,

$(3 a-g)$

上記のシェルの耐力に执いて，シェルの伸び剛性が卓越している 場合は線形補正，曲げ岡性が卓越している場合は 3 次補正，両者が 共に卓越している場合は 2 次補正が，それぞれ有効であると考えら れる。なお，板厚計测結果の一例としてFNNNをFig. 10 に示した。 同図の影付き領域は，載荷点に隣接した限定領域内の板厚を示す。 破壤実験において, シート無補強の RNNN は, 載荷点直下の領域 の板厚がかなり厚く，また FNNN は薄めである。その結果，上記の $\mathrm{EG} 1, \mathrm{EG} 1^{2}$ 及び $\mathrm{EG} 1^{3}$ 各值は整合比が 1 から大きく外れ, $\mathrm{E} 10$ と比 較して，RT12 及び FB11 は, 誤差が増大している。続いて, EL1,
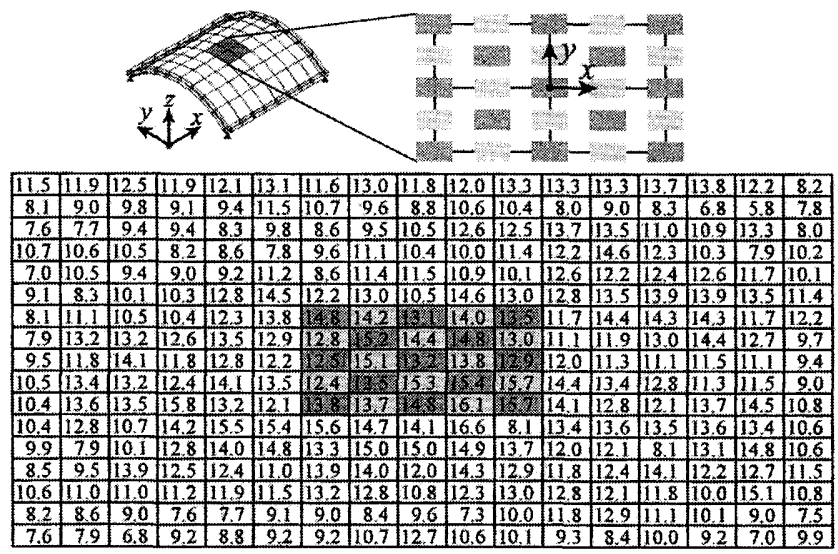

$\stackrel{\iota_{x}}{\longrightarrow} \quad$ Fig.10 Actual Thickness at FNNN.

[Unit:mm]

Table 7 Strength Ratio Adjusted by Shell Thickness.

\begin{tabular}{|c|c|c|c|c|c|c|c|c|c|c|c|}
\hline Strength & E00 & S00 & TG1 & TL1 & E10 & EG1 & EG1 $^{2}$ & EG1 $^{3}$ & EL1 & EL1 $^{2}$ & EL1 $^{3}$ \\
\hline RT12/RNNN & 0.88 & 1.17 & 1.02 & 0.86 & 0.75 & 0.73 & 0.72 & 0.71 & 0.87 & 1.01 & 1.17 \\
\hline RB11/RNNN & 0.80 & 1.37 & 0.91 & 0.70 & 0.59 & 0.64 & 0.70 & 0.77 & 0.85 & 1.22 & 1.75 \\
\hline FT12/FNNN & 1.52 & 1.00 & 1.03 & 1.29 & 1.52 & 1.48 & 1.43 & 1.39 & 1.18 & 0.91 & 0.71 \\
\hline FB11/FNNN & 1.86 & 1.10 & 0.99 & 1.25 & 1.69 & 1.72 & 1.74 & 1.94 & 1.35 & 1.08 & 0.86 \\
\hline Average & & - & - & - & - & 1.14 & 1.15 & 1.16 & 1.06 & 1.05 & 1.12 \\
\hline STDEV & & - & - & - & - & 0.70 & 0.72 & 0.75 & 0.34 & 0.05 & 0.22 \\
\hline
\end{tabular}


$\mathrm{EL} 1^{2}$ 及び EL $1^{3}$ では，いずれの補正においても，E10 と比較して，ほ ぼ1に收束し整合性が確認されている。特に全体でみると $\mathrm{EL}^{2}{ }^{2}$ の 值が, 平均値で 1.05 , 標準偏差で 0.05 が示され, 最も整合性が確 認されている。これはシェルの伸び剛性が板厚に線形比例し，曲げ 剛性が板厚の 3 乗に比例することに注目すると, その中間值, 即ち 面内の伸び剛性と面外の曲げ剛性が連動したシェル特有の複合剛性 に対寸る板厚補正が有効に作用しているものと考えられる。

一方, S00の值より, 炭素瀻維シートによる終局耐力補強効果は, $\mathrm{RC}$ 造で $17 \%$ 増から $37 \%$ 増, CFCRC 造で $0 \%$ 増から $10 \%$ 増が示され, $\mathrm{RC}$ 造での効果が著しいことが示された。加えて，部分的なシート 補強を行うことによりその補強領域による耐力増大の度合いが確認 された。これらの結果は，上記の一連の耐力整合比を考慮すると， 実験的にもシート補強の効果を確認したものと考えられる。なお， RNNN 及び FNNN の基淮モデルによる終局酎力は，2.24kN 及び $3.45 \mathrm{kN}$ であり，限定領域平均板厚は，それぞれ $14.41 \mathrm{~mm}$ 及び $8.96 \mathrm{~mm}$ であっ た。

\section{3 荷重変位曲線}

載荷実験より得られた荷重変位曲線を数傎解析結果と比較して Fig. 11 に示した。同眓は載荷点直「の鈖值方向変位を示している。 また，数值解析は平均及び個別板厚モデルの双方を掲載している。 同図 (b) の寒験值は，機械式ダイヤルゲージとマグネットスタンド の取り付け部ネジの不具合により㓮性が低く評価されている。同計 算值は，同図 (a) より低い耐力を示しており，これは RNNN $の$ 平均

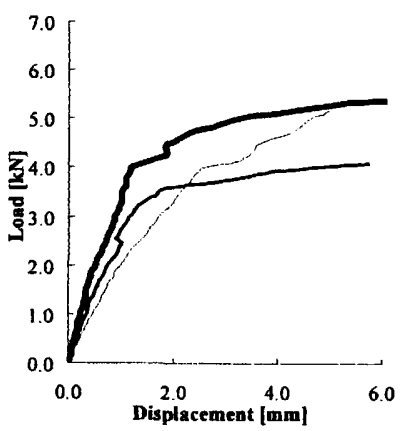

(a) RNNN

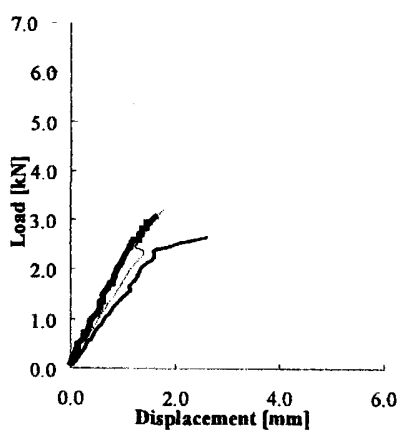

(c) FNNN

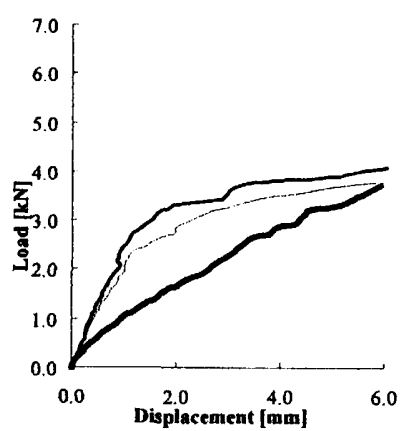

(b) RB11

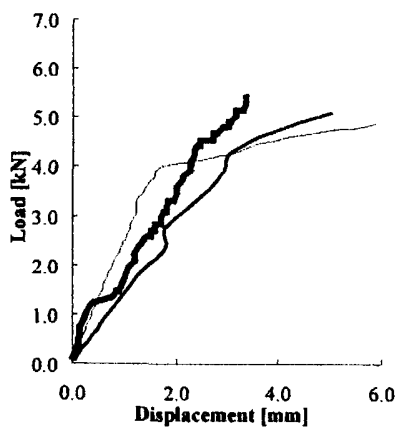

(d) FBII
- Experiment, - Discreet Model, -- Average Model

Fig.11 Displacement vs. Load Curve.
板厚がRB11 より嬮いことに起因していると考えられる。同図より シート補強の無いRNNN 及び FNNN の寒験結果に対して，個別板厚モ デルは，平均板厚モデルと同等またはそれ以上の良い対応を示して いる。しかし，シート補強を行った場合に，上述の理由でRB11は 実験値との直接の比較が困難であるが, FB11 は，初期剛性において， 個別板厚モデルと比較して，平均板厚モデルが多少良い対応を示し ている。

今回の破壊実験から，鉄筋コンクリート造に関しては，シート補 強のタイプRB11 の変形が把握できていないこと及びシート無しの タイプ RNNN の板厚が厚いこと等より，明確な特徽は確認できない が，炭素短繊維コンクリート造の FNNN と複合炭素瀻維補強コンク リート造の FB11 との比較において, 明確に弾性範囲の増大と変形 能力の増大が確認される。

\section{4 シェルの破壊形態}

シェル板厚変動及び炭素緎維シート補強の有無並びに補強籁囲 の相違がシェルの破壊形態に及ぼす影響に関して検討を行った。 Fig. 12 に破壊実験，個別及び平均板厚モデルに於けるひび割れ形 態を，施工シェル板厚変動分布图と其に示した。同図より，CCFRC 造の実験及び個別板厚モデルの数値計算に於いては，シート補強を 載荷点から㕍して設置した場合のFT12 に於いて，ひび割れが載荷 点からシートを避け板厚の薄い部分へと伸びていることが確認され た。平均板奨モデルに扔いて，終局耐力が実験及び個別板陧モデ ルの結果より增大し，終局状態のひび割れ堿少は確認されない。

CFSRC 造及びRC 造に於いては, CCFRC 造及び CFCRC 造と比較して， シェル全面のひび割れ発生が特徵的である。しかし，CFSRC 造では $\mathrm{RC}$ 造と比較して、シート補強によるひび割れ抑制効果が確認された。 この傾向は，破壊実験において顥著に認められる。数值解析におい ては，破壊実験ほど顕著ではないが，ひび割れ低減の傾向は確認で きる。

以上より，実験及び数値解析結果からシート補強範囲がシェルの ひび割れ形態に及ぼす影響を確認した。

5. 結論

本研究では，炭素瀻維シート補強がシェル構造の耐力に及ぼす影 響を検討した結果，以下の結諭を得た。

（1）複合炭素瀻維補強コンクリート造において，載荷点直下の炭 素瀻維シート補強は，シェルの耐力増大に効果的であることが，破 壊実験及び数值解析結果より示された。しかし，引張応力場が支配 的でなく，載荷点から離れた領域を対象としたシート補強の場合に は，若干の耐力低隇を招く可能性が示された。

（2）炭素䋐維シート補強コンクリート造においては，今回対象と した全てのシート補強領域において，耐力増大が確認された。耐力 は，複合孷素瀻維補強コンクリート造と比較して，大幅に増大寸る ことが確認された。

（3）実験で得られた耐力は，載荷点近傍領域の施工板厚に基づく 耐力補正を適用することにより，数値解析によるシート補強効果と 対応した整合性のあるシェルの耐力の評価が確認された。 
（4）シート補強によるひび割れ低減効果は，破壊実験により顕著 に確認された。更に, 今回の炭素短繊維補強コンクリート造と複合 炭素繊維補強コンクリート造の荷重変位曲線から，シート補強によ る弾性範囲及び変形能力の増大が確認された。

（5）数值解析に於いてシートをモデル化するためには，本論で定
義した, 面内せん断剛性を考慮しない直网性タイプで引張及び圧縮 強度並びにヤング係数を炭素緎維シートと同一にした場合に最適值 を得ることが示された。
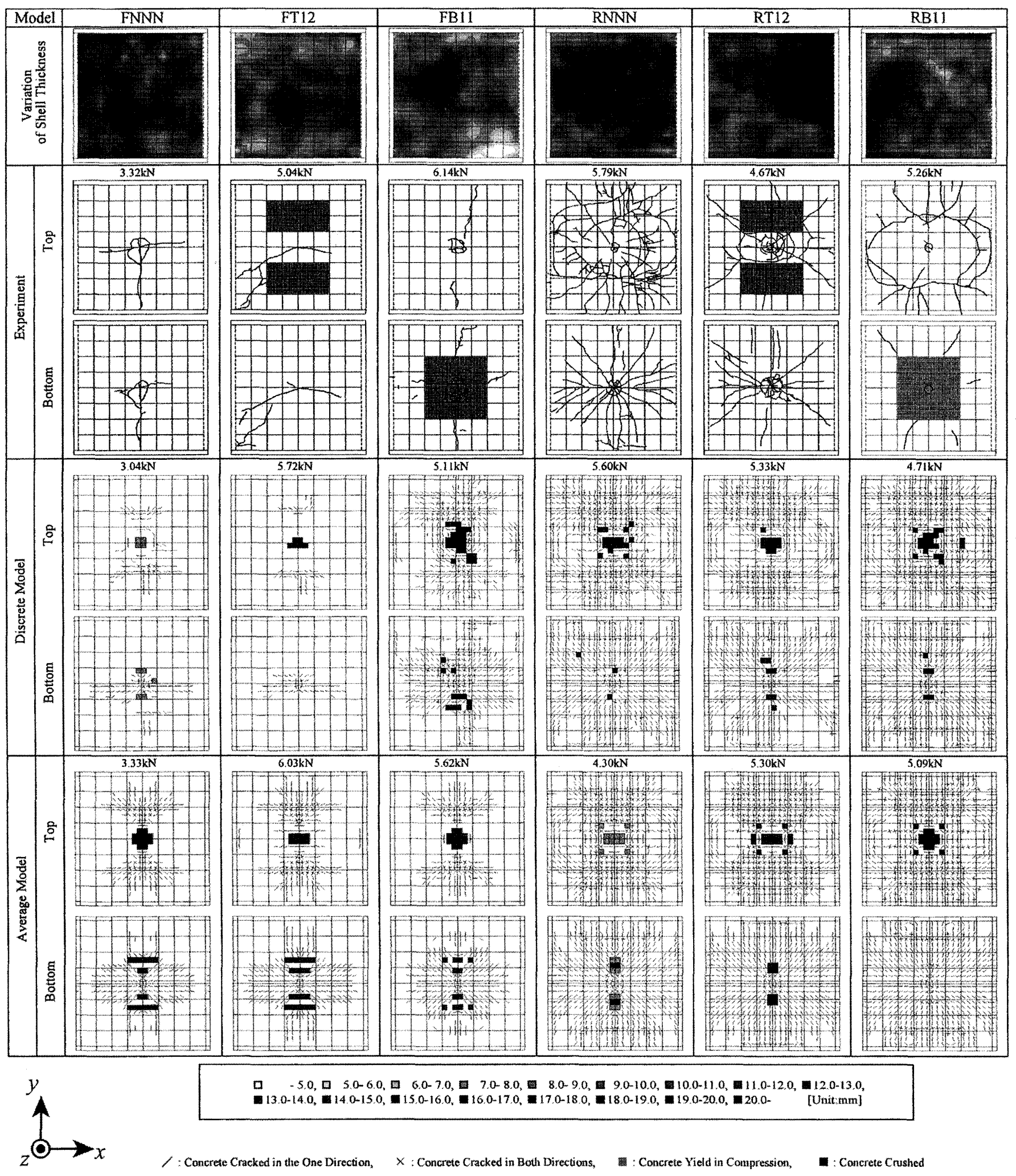

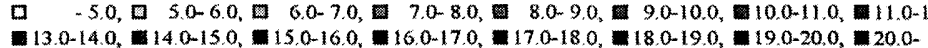

[Unit:mm

Fig. 12 Cracking Pattern at Ultimate Strength. 
カニズムとしては, シェル面のコンクリート引張強度が強化され， 初ひび割れ荷重の上昇, 即ち弾性域の上昇をもたらし, 結果として ひび割れ抑止之終局耐力の上昇効果がもたらされる。これらの傾向 は, 複合炭素瀻維補強コンクリート造の荷重変位曲線，破壊実験の ひび割れ形態, 並びに破壊実験及び数值解析の終局耐力より確認さ れている。今後, 繊維シート貼り付け面の規模や鉄䈘比を変化させ た破壊実験並びにより詳細な数値モデルの構築等により，更に精密 な効果が抽出できるものと期待される。その応用として，損傷を受 けたシェルの修復や脆性的な破壊の防止，よりシェル面の均質な補 強等への発展が期待される。

\section{謝辞}

本研究の一部は, 文部科学省平成 15 年度科学研究費補助金（基 盤研究 (c) (2)) (課題番号:15560498, 代表:真下和彦)によるもので, 深謝致します。本研究の資料作成にご協力いただきました須永耕平・ 熊本千大両氏に厚く㧍礼申し上げます。

参考文献

1）加藤 涉, 倉田博, 細谷隆二, 榎並 昭, 西村敏雄: シャ一 レン (曲板) 屋根の終局荷重設計法に関寸る実験的研究 (その4), 日本建築学会論文集，第 54 号，頁 $329 \sim 332 ， 1956.9$

2）坪井善勝，青木 繁，酒井 康，川口衛：水平力を受ける円 筒款の実験的研究, 日本建築学会論文報告集, 第 54 号, 頁 345 $\sim 348,1956.9$

3）エドゥアルド・トロ八，川口衞 監修・解説：エドゥアル ド・トロハの構造デザイン, IASS2001 組織委員会 訳, 相模書房, 2002.9
4）國枝治郎, 加藤史郎, 高山誠, 半谷裕彦, 真下和彦, 皆川洋一, 山田聖志 :〔鉄筋コンクリートシェル酎荷力実験資料集」, 日本建 築学会, 連続体構造小委員会, 1993.3

5）皆川洋一：裾梁を有する直交異方性円筒シェル屋根の解析 解之静的挙動，日本建築学会構造諭文報告集，第 463 号，頁 75 $\sim 84,1994.9$

6) Scordelis, A. : Nonlinear Material, Geometrical and Time-Dependent Analysis of Reinforced and Prestressed Concrete Shells, Proc. IASS, Madrid, pp. 57-70, 1989.9

7）高山 誠, 中村博志, 加藤史郎 : 形状初期不整を有する鉄 筋コンクリート円筒シェルの破壊性状と最大耐力に関する実験と 数值解析の比較, 日本建築学会構造系論文報告集, 第 429 号, 貢 $111 \sim 124,1991.11$

8) J. G. Teng and L. Lam, Compressive Behavior of Carbon Fiber Reinforced Polymer-Confined Concrete in Elliptic Columns, J of Structural Engineering, ASCE, pp. 1535-1543, 2002. 12

9）真下和彦，小林 剛：点荷重を受ける開口部付き炭素短㵶維 補強コンクリート造円筒殼の耐力, 日本建築学会構造系論文集, 第 539 号, 頁 79-86，2001.1

10）石井良和，真下和产，永井啓二，「線荷重を受ける CFRC 円 筒殼け耐力（その1.）破壊実験」，日本建筮学会大会梗概集，頁 $851 \sim 852,1998.9$

11) 石井一大, 膜構造の応力 - 変形解析概説, 膜構造研究論文 集' 90 ，膜構造協会，pp.69-105，1990.12 